TERCÜME MAKALE / TRANSLATION:

KUR'AN TEFSIRINDE MU'TEZILE RASYONALIZMI

“Hamid Aryân: Ma'na ve Mebnayı Aklgerayi-i Mu'tezile Der

Tefsir-i Kur'an, Kur'an Şınaht, 6:I, (1392): 5-25"

\author{
Çeviri: \\ Naim DÖNER \\ Yrd. Doç. Dr., Bingöl Ü. İlahiyat Fakültesi \\ ndoner@bingol.edu.tr
}

\title{
Giriş
}

Mu'tezile, dinî mearif/bilgiler alanında düşünsel-mezhebi hareketlerin en ünlüsüdür. Mutezilî düşünürler, her şeyden önce ve her şeyden çok, dinî esasları, özellikle Kur'an ayetlerini anlama ve yorumlamada "metodik" olarak aklî tefekküre ve bir kaynak olarak da "aklî idraklere" vurguda bulunmuşlardır.

Bu kelamî akım, takriben, hicri birinci asrın sonları ile ikinci asrın başlarında ehl-i beyt (a.s) takipçileri hariç, o dönemde gündemde olan hadis ehli, Havaric, Murcie, Kaderiyye, Mücebbire, Mücessime gibi mezhepler arasında fikrî ve mezhebî çekişmelerin cereyan ettiği bir ortamda ortaya çıkmıştır. Mu'tezilî olmanın temel ölçütü, -bu nazariyenin asıl kurucularının ifadesine göre- bu mezhebin bilinen beş ilkesine/usûl-i hamse inanmaktır. ${ }^{1}$

Dinî düşünceyi yeniden ve derinlemesine tanımayı hedefleyen bu makale, betimlemeye ve tahlile dayalı bir metot ile Mu'tezile'nin Kur'an tefsirinde akla yönelişini araştırmaktadır. Dolayısıyla bu konuda haklı olarak önemli bir takım sorular gündeme gelmektedir. 1. Kur'an tefsirinde Mu'tezile rasyonalizminden/akla yöneliminden maksat nedir? 2. Bu rasyonalizm hangi esaslara dayanmaktadır? 3. İtizâlî akılcılık, hangi ayetlerin tefsirinde işletilmektedir? 4. Mu'tezile rasyonalizmi, onların tefsirlerinde ne tür neticeler ortaya koymuştur. 5. Mu'tezile akılcılığının Kur'an tefsirinde sahip olduğu kuvvetli ve zayıf noktalar nelerdir? Bu makale, söz konusu sorulardan sadece birinci ve ikinci soruya cevap verecektir. Diğer soruların cevabı ise başka bir alanı ilgilendirmektedir.

Hayyat, Ebu'l-Hasan Abdurrahim b. Muhammed, el-Intisar, tahkik: Muhammed el-Hicazî, Mektebetu'-sekâfe, Kahire 1988, s. 188-189. 
İlk değerlendirme olarak Kur'an tefsirinde Mu'tezile rasyonalizmi, müstakil olarak çok az şekilde araştırılmıştır. Bununla birlikte "dini marifet/bilgi" konusunda Mu'tezile'nin eğilimi, bazı uzmanların dikkatinden kaçmamış, fakat bu, din-akıl ve bazen de akıl-vahiy bağlamında gündeme getirilmiştir. Çok az kaynakta bu mesele, hem zımni bir şeklide hem de bazı temel esasları sadece mücmel olarak ifade edilmiştir. Her ne kadar bu kaynak eserler, kendi alanlarında önemli olsa da yine de bunların hiç birinde "tefsirde aklın yeri" ve özel bir tarzda "Kur'an tefsirinde Mu'tezile rasyonalizminin temeli ve anlamı" ve bununla ilgili konular müstakil bir şekilde araştırılmamıştır.

Öyle anlaşılıyor ki Kur'anî ve kelamî araştırmalarda buna bağlı olarak tefsire dair önemli eğilimlerin ve kelâmî nazariyelerin temel ilkelerini tanıma konusunda bu tür makalelere bağımsız bir şekilde yönelmek ufuk açıcı/yol yol gösterici ve yararlı olacaktır. Bu tür çalışmalar, kendi adına grupları daha da şeffaf hale getirme, fırka ve mezheplerin fikri ve itikadî ihtilafların nedenini, kelamî inançların tesirlerini ve bunların zararlarını anlamada yardımcı olacaktır. Bu makale üç ekseni içermektedir: Birinci eksende Mu'tezile'nin ana düşüncesine kısaca işaret edildikten sonra Mu'tezilî düşünce sisteminde "akl" 1 anlam ve mefhumu tasvir edilecektir. İkinci eksende "Kur'an tefsirinde Mu'tezile rasyonalizmi"nden maksat açıklanıp değerlendirilecektir. Üçüncü eksende ise Kur'an tefsirinde Mu'tezile'nin akılcı bir eğilim ve yol tutmasına sebep olan en önemli düşünsel esasları zikredilecektir.

$\mathrm{Bu}$ eksene dair konulara geçmeden önce iki noktayı hatırlatma zarureti bulunmaktadır:

1. Bu makalede, esas olarak büyük Mu'tezilî düşünür Kâdi Abdulcebbar'ın, bazen de Zemahşerî'nin eserlerinden istifade edilmiştir. Zira her iki düşünür, kelam sahasında ve Kur'an tefsirinde bu hareketin görkemli düşünce dağının zirvesinde bulunmuş ve kuramcılarından olmuştur. İtizâlî düşüncenin yayılması, devam etmesi ve diğer İslami fırkalar ve mezhepler üzerinde günümüze kadar tesirler bırakmasında onların önemli rolleri olmuştur. Kadi Abdulcabbar'ın Kur'an tefsirinde aklın rolü ve yeri konusundaki görüşleri, Müteşabihu'l-Kur'an ve Tenzihu'l-Kur'an ani'l-metâin gibi Kur'an'a özel eserleri ile ansiklopedi mahiyetindeki el-Muğnî fì ebvabi't-tevhîd ve'l-adl adlı eserinde bulunabilir. Elbette bu arada, önemli bir eser olan Şerhu usûli'l-hamse kitabının payını da görmezden gelmemek gerekir. Kadî, bu eserlerin her birisinde Mu'tezile'nin düşünce ve inançlarını, dinsel bilgide aklın işlevi ve konumunu ve Kur'an ayetlerinin tefsir edilmesinin niteliği konusunu güzel bir şekilde ifade ederek göstermiştir. Genel olarak dini bilgi, özel olarak da Kur'an tefsiri alanında aklın rolü ve yeri konusunda Mutezilî görüşlerin yansıtılıp değerlendirmesi için

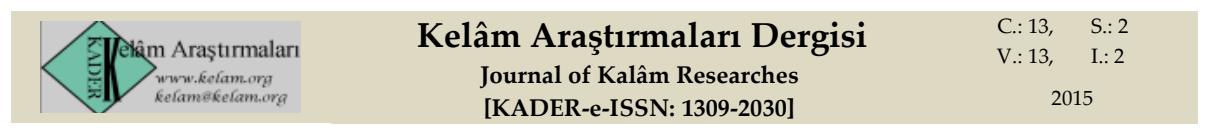


Zemahşerî̀nin el-Keşşaf'ı da diğer şeffaf bir kaynaktır. Bu kitap, İtizâlî bir metotla hazırlanmıştır. Zemahşerî, -kendi ifadesiyle- bu eserde sultan yani ilim ve burhan bayrağ 1 altında hareket etmeye çalışmıştır. Bu nedenle esere, İtizâlî rasyonalizm için nispeten kapsamlı bir kaynak olarak itimat edilebilir.

2. Bu makale, üçüncü eksende Mu'tezile'nin tefsir kaynaklarını araştırmanın peşinde değildir. Belki bu eksen, Kur'an'ı anlamada Mu'tezile'nin aklî bir bakış açısına yönelmesine neden olan esas payeyi, Kur'an tefsirinde rasyonalitelerinin kaynağını ortaya koymak olacaktır. Yani onların, Kur'an ayetlerini anlama ve yorumlama konusunda akla yönelmelerinin nedenini aydınlığa kavuşturacak ve onların neden nassç̧lığı ya da başka eğilimleri kabul etmediklerine dair bir takım bilgiler verilecektir. Tefsir kaynakları konusuna gelince müfessirin daha önceden kabul etmiş olduğu ve Kur'an ayetlerinden elde ettiği verileri bunlar üzerine bina etmiş olduğu bütün temel kaynaklara girişilecektir. Bununla birlikte Mu'tezile'nin tefsire dair kaynaklarını derinlikli olarak izahı da bu yazıdan beklenmemelidir. Çünkü bu, başka bir konudur.

\section{Mu'tezile Telakkisinde Akıl}

Dinî bilgi alanında Mu'tezile'nin metot ve eğilimi esasen rasyoneldir. O çağda onun popüler olan bu rasyonel yönelişine ve metoduna mukabil, "sassgerâyî/nassçılık", yer almaktadır. Akılsal bu yönelimin, halifeler okulu takipçileri arasında din bilim alanında kendi hesabına yeni bir yol bulduğu söylenebilir. Bu husus, bazı Ehl-i sünnet düşünürlerini, "esasen İslam dünyasında akılcılık düzeni, Vasıl b. Ata (ö. 131/748) aracılığıyla hicri ikinci asrın başlarında Mu'tezile inancının tesisiyle kurulmuş oldu". şeklindeki bu abartılı inancı ifade etmeye sevk etmiştir. ${ }^{2}$

Şüphesiz, Mu'tezile'nin ve akla dayalı bu metodunun dikkat çekici bir şekilde yayılmasının en önemli faktörü, takip ettiği bu akılcı yol olduğunu bilmek gerekir. Bu akılcı metodun büyük kısmının, onların itikadî ve düşünce sistemine uyması, dinî değerleri ve Kur'anî ayetleri düşüncelerine uygun bir şekilde tahlil ve tefsir etmeye, özellikle insan yazg1sı, ilahi kader ve kaza, insanın irade ve ameli gibi ilahi sıfat ve filler alanında görüş belirtmeye sebep oldu. Buna ek olarak söz konusu bu yöntem, ister içte diğer İslami fırka ve mezheplerle rekabette, isterse Yahudilik, Hristiyanlık ve Sâbiîlik gibi diğer dinlerle yüz yüze gelmede rakip düşünce ve fikirler karşısında Mu'tezile âlimlerini sağlam ve keksin bir silah ile donattı. Böylece onlar, buna dayanarak ilmî ve dinî münakaşa ve münazaralarda ne diğerlerinin fikri verilerinden korkup kaçtı ne de rakiplerinin yararına meydanı boş bıraktılar. Böylece Zahirîler, hadis ehli, Hanbelîler, Mücessime

2 Lahorî, Muhammed İkbal, Seyr-i Felsefé der İrân, Emir Huseyn Âryanpûr, İntişarat-i Emir Kebir, Tahran 1357, s. 44.

\begin{tabular}{|ccc} 
Kelâm Araştırmaları Dergisi & C.: 13, & S.: 2 \\
Journal of Kalâm Researches & V.: 13, I.:2 \\
[KADER-e-ISSN: 1309-2030] & 2015
\end{tabular}


ve Bâtıniler, Mu'tezile'nin rasyonalist eleştirileriyle karşı karşıya kaldılar. Yukarıda ifade edilen hareketlere karşı eleştirilerinde Mu'tezile'nin kelam ve tefsire dair düşüncelerinin başarısı, işte bu akılcılığa borçludur. Bütün bu rakiplerin ortak zaaf noktası, dinî marifet konusunda akıldan kaçış ve bazen de akıl ile savaştı. Onlar, Mu'tezile'nin rasyonalist mantığına karşı zararlı çıktılar. $\mathrm{Bu}$ nedenle Mu'tezile'nin akıl telakkisinde, aklın anlam ve mefhumunu tanımak, onların akılcılı̆̆ını anlamak için, dinî bilgi ve Kur'an tefsirinde ilk adım olarak önemlidir.

Mu'tezile'nin meşhur âlimlerine göre akıl ilk bilgilerin toplamından ibarettir ki, genel olarak akıl, fertler için zorunlu olarak hâsıl olur. Bütün akıllılar bu miktar bilgiden istifade etme konusunda eşittirler. Akıllılar, ilk bakışta, zulmün kabih olduğuna ve iki zıddı bir araya getirmenin imkânsız olduğuna hükmetmek gibi aklî bir iş konusunda pratik olarak aynı fikirde olurlar.

Kadı Abdulcebbar, el-Muğnî adlı kitabında aklın ne olduğuna dair müstakil bir fasıl açmış ve orada aklın anlam ve mahiyeti konusunda Mu'tezile'nin görüşünü güzel bir şekilde açıklamıştır. ${ }^{3}$

O, şöyle der: Akıl özel ilimlerin bir toplamıdır ki, şayet mükellefte ortaya çıkarsa kişinin, nazar, istidlal ve teklifi yerine getirmesi mümkün olur. ${ }^{4}$ Kadı Abdulcebbar'dan önce hocası Ebu Ali Cübbâî de Mu'tezile'nin bir bakış açısı olarak bu konuyu şöyle ortaya koymuştur: Akıl, bilgiler toplamıdır. Gayri iradî ve zorunlu olarak insana verilir. Bu bilgiler toplamı bireyde yekinliğe/kemale erdiği zaman istidlal, nazar ve istitaat gibi teklifi eda etme onda ortaya çıkar. ${ }^{5}$

Kadı Abdulcebbar, bu noktayı ayrıntılı olarak açıklar: Akıl, kuvvettin ve duyu organının bir aleti değildir. Belki o, ilim türünden bir şeydir, der. ${ }^{6}$

Mu'tezilî düşünürlerin anlayışına göre bir kimsenin sırf bilgiden ve başlangıç bilgilerinden istifade etmesi ile "kendisi için akıl meydana gelmiştir" söylenemez. Belki mutlak olarak aklın husule gelmesi, doğru bilgilerin özel bir derecesiyle meydana gelir. İlmin bu derecesi Mu'tezile terminolojisinde 'aklın kemali/yetkinliği' olarak ifade edilir. Onun hâsıl olmasıyla teklif de ortaya çıkacak, buna sahip olan kimse, istidlal ve nazara da güç getirebilecektir.?

Kadı Abdulcebbar'a göre insan için meydana gelmesi gereken ve kendisine "akl" denecek kadar yığılan bilgilerin (toplam) yükünü, belli değildir. Zira aslında bundan amaç, bizzat bilgilerin tahakkuk etmesi değildir. Belki bu

\footnotetext{
Kadı Abdulcebbar, Ebu'l-Huseyn el-Hemedânî el- Mŭ̆ni fi Ebvabi't-tevhid ve'l-'adl, tahkik: Muhammed Mustafa Hilmî ve diğerleri, Daru'l-Misriyye, Misır, 1385, XI, 375-387.

Kadı Abdulcebbar, aynı yer. s. 375.

Eş'ârî, 1400, s. 480-481.

Kadı Abdulcebbar, 1385, XI, 375-377.

Kadı Abdulcebbar, 1385, XI, s. s. 386.
}

\begin{tabular}{|ccc} 
Kelâm Araştırmaları Dergisi & C.: 13, & S.: 2 \\
Journal of Kalâm Researches & V.: 13, & I.: 2 \\
[KADER-e-ISSN: 1309-2030] & 2015
\end{tabular}


bilgilerden amaç, kendisiyle ilimlerin kesp edildiği ve teklifin eda edildiği bir mertebedir. Bununla birlikte aklın yetkinliğine ulaşmak için bu miktar bilgi de gereklidir ki, onun var olmasıyla bilgileri iktisap etmek de kolaylaşır ve buna sahip olan kimse için de vacipleri eda etmek mümkün hale gelir ${ }^{8}$

Kadı, aklın kemal mertebesinin hâsıl olması için gerekli olan bilgileri şu şekilde ifade eder:

1. İrade, kerahet ve itikat gibi kendi özel hallerini bilmek.

2. Cisimlerin ictima/bir araya gelmesine ve iftirakına/ayrılmasına ilişkin halleri bilmek,

3. Zulmün, küfran-1 nimetin, faydasız; yalanın kabih/ çirkin olduğunu; ihsan ve lütfun husun/iyi ve munime/nimeti verene şükretme ve emanete riayet etmenin vacip olduğunu bilmek gibi bir takım husun ve kubuhları bilmek,

4. Pek çok devaî'yi bilmek.

Kâdi Addulcebbar'ın inancına göre teklif makamında insan için ilimlerin bu miktarını bilmek, zorunludur. ${ }^{9}$ Bunlar, insanın akl ile nitelenmesi ve ona "âkil" diye hitap edilmesi için insanda mutlaka ortaya çıkması gereken ilimlerdir. Şâri' tarafından böyle bir insana teklifte bulunulması -diğer koşulların meydana gelmesi kaydıyla- hüsündür, iyidir. ${ }^{10}$

Kâdi Abdulcebbar'ın düşüncesine göre bu bilgiler yığını, terminolojide "aklın kemali" olarak ifade edilir. Bu nedenle onların var olmasıyla teklif "hüsün" hale gelir. Eğer bu miktar bilgi insanda meydan gelirse insan için (aklın kemali) nazar, istidlal mümkün hale gelir. O, "Aklın kemali"nin ortaya çıkması amacıyla teklifin edası için ilim ve amel ile ilgisi bulunan her türlü bilgiyi gerekli görmekte ve bu konuyla ilişkisi bulunmayan ilimlerin de aklın kemali ile ilgisini geçersiz saymaktadır. ${ }^{11}$

Kadı Abdulcabbar'ın izahına göre bu ilimlerin "akl" olarak adlandırılmasının nedeni iki şeydir:

1. Tipkı deve yularının onu herhangi bir yere girip çıkmasını engellediği gibi bu ilimler de insanı aklın beğenmediği istek /arzulardan alıkoyar.

2. $\mathrm{Bu}$ ilimlerin var olmasiyla birlikte fehm/anlama ve istidlal/çıkarsama ile ilgisi bulunan diğer bilgiler de sabit ve muhkem hale gelir. Bu açıdan bunlar deve ağzına vurulan ve

Kadı Abdulcebbar, 1385, XI, 379.

Kadı Abdulcebbar, 1385, XI, 385.

Kadı Abdulcebbar, 1385, XI, 386.

Kadı Abdulcebbar, 1385, XI, 380.

$\begin{array}{ccc}\text { Kelâm Araştırmaları Dergisi } & \text { C.: 13, } & \text { S.: } 2 \\ \text { Journal of Kalâm Researches } & \text { V.: 13, } & \text { I.: } 2 \\ \text { [KADER-e-ISSN: 1309-2030] } & 2015\end{array}$


onu sabitleyen geme benzerler. ${ }^{12}$ Eş'ârî'nin nakline göre Ebû Ali Cübbaî (ö. 303/916)'nin bakış açısı da aynı yöndedir. ${ }^{13}$

3. Elbette Mu'tezile'den felsefeye yönelen Ebu'l- Huzeyl Allaf (ö. 235/849-50) gibi bazıları, aklın iki kısma ayrıldığı görüşündedir:

a. Akıl, 1ztırarî/zorunlu olarak ortaya çıkan bilgiler toplamıdır. Böylece kişi, onlar vasıtasıyla kendisi ile merkep, gökyüzü ve yeryüzü arasındaki farkı ortaya koyar.

b. Akıl, bilgiyi kesp etme güç ve kuvvetidir.

Bununla birlikte Kadı Abdulcebbar ve Ebu Ali Cubbâî gibi Mu'tezile'nin önde gelen büyük mütefekkirlerin eserlerinden yansiyan bilgilere göre Mu'tezile'nin yaygın ve popüler olan akıl telakkisi şudur: Akıl, nefiste idrak ve istintac işlevi gören bir kuvve/potansiyel değildir. Onlara göre tam tersine akıl, ilmin kendisidir ve bu nedenle "akl" diye ifade edilmiştir ki, akıl, insanı, delinin yapmaktan sakınamadığı işleri yapmaktan alıkoyar. ${ }^{14}$ Elbette her türlü bilgi değil, belki, kabih/kötü işlere mani olan, iyi işlere çağırıda bulunan bir bilgi mertebesi iyidir ve bu mertebe ile nazar ve istidlalde bulunma müyesser olur ve onun vasitasıly ilimleri kesp etme ve teklifi/yükümlülüğü yerine getirme mümkün olur.

\section{Kur'an Tefsirinde Mu'tezile'nin Akılcılığa Yönelişinin Anlamı}

Kur'an tefsirinde Mu'tezile akımının somut en belirgin özelliği "akılcılık" olduğuna göre doğal olarak her şeyden önce bu akılcılığın anlamını ve esaslarını açıklamak gerekir. Daha sonra da onların metinlerine ve tefsire dair düşüncelerine giriş yapılabilir.

Kur'an tefsirinde Mu'tezile rasyonalizmi/akılcılığı gerçekte özel bir bakış açısına sahiptir. Onların, bu konuda aklın yeri ve konumuyla sıkı ilişkileri vardır. Bu bakış açısı, onların düşüncesinde iki esastan kaynaklanmaktadır:

1. Aklın diğer delillere öncelenmesi: Bu esasa göre aklın, dini anlama ve dini bilgi konusunda diğer delillerden önce geldiği kabul edilir.

2. Dinî metinlerin aklî esaslar bağlamında anlaşılması: Yani, dinî metinlerin ve nassların maksudu, bu cümleden Kur'an ve onun sıhhati de olmak üzere -kendi kendilerine değil- belki aklî

\footnotetext{
Kadı Abdulcebbar, 1385, XI, 386.

13 Eşârî, Ebu'l-Hasan, Mekâlâtu'l-İslâmîyyin ve ihtilafu'l-musallin, (3. baskı), Daru'n-neşr, Beyrut, s. 480.

14 Husnî Zeyne, el-'Aklu inden'l-Mu'tezile, Tasavvuru'l-'Akl inde Kadi Abdilcebbar, Daru'l-âfâk, Beyrut 1978, s. 33.
}

\begin{tabular}{|ccc} 
Kelâm Araştırmaları Dergisi & C.: $13, \quad$ S.: 2 \\
Journal of Kalâm Researches & V.: $13, \quad$ I.: 2 \\
[KADER-e-ISSN: 1309-2030] & 2015
\end{tabular}


esaslar ışığında anlaşılmaya kabildir. İleride bu iki konuya değineceğiz.

\subsection{Aklî Delilin Diğer Delillere Öncelenmesi}

Mu'tezile anlayışında "aklın öncelenmesi" onun nakilden önce esas alınmasına karar kılınması ve naklin de ona tabi kılınması anlamına gelir. Elbette bu önceleme, hakikî değil, hiyerarşiktir. Bu takdim gereği, dinin ve ona tabi öğretilerinin kabulü, rasyonel olacaktır. Bu şu anlama gelir: Aklî delil, dinî bilginin elde edilmesinde sıralama/rütbe açısından diğer delillere göre, birinci derecede yer alır ve onun verileri asil ve müstakildir. Binaenaleyh, akıl, dinî bilginin kaynağı konusunda diğer delillerin başında ve onlardan önce gelir.

Başta Eş'arîler olmak üzere Mu'tezile'nin diğer bütün zahire yönelen muhalifleri ile temel ihtilaf ve tartışmasının kökeni, dini marifet konusunda akıl rütbesinin takdim veya tehir edilmesi noktası üzerinde cereyan etmektedir. Mu'tezile bakış açısına göre aklın rütbesi önce gelir, fakat zahire yönelenler ise semî’ (şerî̀) delilin, aklî delilden önce geldiği kanaatindedir.

Mu'tezile tarafından aklî delilin öncelenmesinin sırrı, onların düşüncesinde "nazar"ın konumunu iyi bir şekilde bilmekle yakından ilişkisi vardır. Onların bakış açısına göre, Kur'an'ı okuyan ve onu indiren Tanrı'yı tanımanın vacip olması, aklî bir gerekliliktir. Onlar, bunu da "nazarın vucübü/düşüncenin zorunluluğu" olarak ifade ederler. Dinî bilgi ve Kur'an'1 anlama konusunda aklî bir unsur olarak "nazar ve istidlalin vucübü", Mu'tezile'nin vurguladığı bir husustur. Onlara göre bizzat nazarın vücübu da semî‘ değil, aklî hükümlerdendir. ${ }^{15}$

Kadi Abdulcebbar şöyle der: "Allah'ın bize vacip kıldığı ilk husus, marifetullah ile neticelenen bir nazardan ibarettir. Zira Allah, hissî müşahede ile değil, zarurî olarak ve aklî hidayet ile tanınır. Bu nedenle O'nu tefekkür ve nazar ile tanımamız vaciptir.16 $\mathrm{O}$, şuna inanır: Her akıllı kimsenin aklında kendi vasıtasıyla nefisten zararın defedildiği nazarî bir vücub bulunmaktadır. ${ }^{17}$ Öte yandan akıl vasıtasıyla Tanrı'yı tanımadan, nakle yapışmanın imkânı da yoktur. Buna ilaveten aklî delil, gerek nazarın ispatının lüzumu açısından gerek marifetullahı elde etmenin vücubu açısından diğer dinî bilgilerin önünde ve diğer delillerden önce gelir.

Kadi Abdulcebbar, Allah'ın asıl muhataplarının akıl sahipleri olduğunu delil getirerek aklı esas almayan, kaynak oluşunu ve önceliğini kabul etmeyenlerin görüşlerini reddetmektedir. Pek çok kimsenin bu tertibe (aklın diğer delillere takaddumu) oldukça şaşırmış olduğunu, dinin delil ve kaynaklarının sadece kitap, sünnet ve icma olduğunu zannettiklerini ya da

15 Kadı Abdulcebbar, 1385, XII, 347; Şenuka, Said, et-Te'vil bi't-tefsir beyne'l-Mu'tezile ve'ssünne, el-Mektebetu'l-ezheriyye-Daru'l-vefa, Misır, ts., s. 96-100.

16 Kad1 Abdulcebbar, 1408, s. 39.

17 Kadı Abdulcebbar, aynı yer, s. 67.

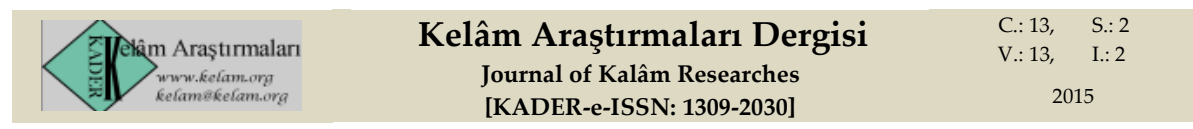


aklın bir delaleti varsa rütbesinin diğer delillerden sonra geldiğini sandıklarını; hâlbuki gerçekte durumun böyle olmadığını, zira Allah Teâlâ'nın sadece aklı başında olanları muhatap kabul ettiğini, binaenaleyh, bu konuda aklın asıl ve esas olduğunu ifade etmektedir.18

Kadi Abdulcebbar'ın sözlerinde bazen aklî delile nispetle diğer delillerin fer' olduğuna vurgu yapılmıştır. "Deliller dört tanedir: Akıl, kitap, sünnet ve icma. Allah Teâlâ'yı tanıma, sadece akıl yolu ile hâsıl olur. Diğer deliller (kitap, sünnet icma ) ise tevhit ve adalete uygun bir şekilde Allah'ı tanıma konusunda fer' (delil)dir. Şu halde bu delillerden biri ile Allah'a dair istidlalde bulunursak gerçekte bir şeyin fer'i ile aslına istidlalde bulunmuş oluruz $\mathrm{k}$, bu da caiz değildir."19

Kadi Abdulcebbar'a göre aklî delilin kitap ve sünnete teehhür etmesi nadirdir ve kısır döngüyü gerektirir. $O$, şuna inanır: Eğer aklî delil olmaksızın ayetlerden istifade ederek Allah'ı ve sıfatlarını tanımayı istersek totoloji/devir lazım gelir. Zira Tanrı'yı ve sıfatlarını tanıma ayetlerin sıdkına tevakkuf eder, ayetlerin sıdkı ise Allah'ı tanıma ve onun "hakim" oluşuna tevakkuf eder. ${ }^{20}$

Elbette O, şu noktaya da dikkati çeker: Bazen kitabın (Kur'an) asıl (kaynak oluşu) söz konusu edilse de bundan amaç dinî bilgi konusunda onun tertipteki asaleti değildir. Bu söz bile kitabın irşatları ile aklî çıkarmalara geri döner. Kitap, akıl dairesinde bulunan şeylere yönlendirdiği ve hükümlerin delillerini içerdiği için "Kitap, asıldır" deriz. Şu halde akıl vasıtasıyla "fiil"e ilişkin hükümler ile "fail"e ilişkin hükümler arasına fark konabilir. Şayet akıl ortada olmazsa fiili yapmaktan ya da terk emekten dolayı kimin yargılanması ve cezalandırılması ve kimin övülmesi ya da kınanması gerektiğini teşhis edemezdik. Bu nedenledir ki, aklı olmayan yargılanmaz. ${ }^{21}$

Zemahşerî de aklî delilin önemine vurguda bulunmuş, onu diğer delillere ve dinî kaynaklara öncelediğini açıkça ifade etmiştir. O, Kur'an'ın “...her şeyi ayr ayrı açıklayan..."22, mealindeki ayetin tefsirinde şöyle demektedir: Kur'an, din konusunda kendisine ihtiyaç duyulan her şeyin tafsilidir. Zira Kur'an, aklî delillerden sonra sünnetin, icma ve kıyasın kendisine dayandığ bir kanundur. ${ }^{23}$ Kitap ve sünnetin itibarını ve hüccetini akla bağlı sayan Kadi Abbdulcebbar, akıl vasıtasıyla hüsün/iyi ile kubuhun/kötünün birbirinden ayrılacağına inanmaktadır. ${ }^{24}$ Zira Allah Teâlâ, sadece akıllılara hitap etmiş ve akıl vasıtasıyla kitap, sünnet ve icmanın delil oluşu/hücciyeti sabit

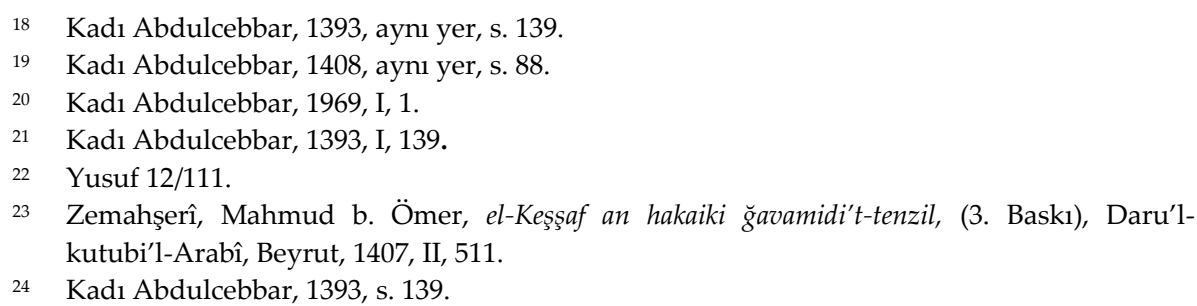

\begin{tabular}{|ccc} 
Kelâm Araştırmaları Dergisi & C.: $13, \quad$ S.: 2 \\
Journal of Kalâm Researches & V.: $13, \quad$ I.: 2 \\
[KADER-e-ISSN: 1309-2030] & 2015
\end{tabular}


olmuştur. Binaenaleyh, akıl, bu konuda asıl ve esastır. Her halükarda Mu'tezile, şeri'n vürûdundan önce dinî bilgilerin asıllarını akıl ile elde etmek gerektiği, Kitap ve sünnetin delil oluşu da akıl yoluyla ispata kavuştuğu inancındadır. Dolayısıyla kitap ve sünnetin hücciyeti ispatlandıktan sonra aklî usul çerçevesinde onlara müracaat caiz olur ve onları doğru anlamak mümkün olur.

\subsection{Aklî Usul İle Dinî Metinleri Anlama}

Kur'an tefsirinde Mu'tezile akılcıllğını tasvir eden diğer bir husus da dinî metinlerin aklî usullerle olan ilgisidir. Şöyle ki, Mu'tezile âlimlerinin görüşüne göre aklî delil olmadan bu metinlerin doğruluk ve delalet yönü sabit olmaz. Bu, şu anlama gelir: Şerî' beyanın ve Kur'anî hitapların maksud ve doğruluğu anlamaya kabil ve onların medlulü de temessük edilmeye elverişli olduğuna göre daha önce Allah hakkında tasdik edilmiş bir dizi aklî verileri kabul etmiş olmalıyız. Onlar, Kur'an ve sünnetin delaletinin sıhhati konusunda aklın fonksiyonunu defaten vurgulamışlardır. Diğer kaynakların/delillerin verdiği bilgilerin de Allah Teâlâ'yı ve sıfatlarını akıl yolu ile tanımaya dayandığı görüşündedirler.

Kadi Abdulcebbar, şuna inanır: Akıl yoluyla Allah'ı tevhit ve adalet vasfıyla, O'nu kadim ve hakim gibi sifatlarla tanımadan önce ayetlerin delaletini ve hücciyetleri, onların muradını anlama ve ayetlerden anlaşılmazlığı nefyetme imkanı olamaz. Şu halde hem itibar, hem doğruluk hem de Kur'an ayetlerinin muradını keşfetme akla bağlıdır. Aynı şekilde akıl, bir karine olarak Kur'an ayetlerinin muradını keşfetmeye müdahildir. ${ }^{25} \mathrm{Bu}$ nedenle Kadı, şuna inanır: Mücebbire, Murcie ve aklın takaddümünü kabul etmeyenler, Kur'an beyanatının sihhatini ve bu beyanların delaletini bilemezler. ${ }^{26}$ Zira ilk aklî yargılar olmadan nakle dayalı kaynakların sıhhati ve hücciyeti/delil oluşu ispat edilemez ve onların delalet yönleri de bilinemez. Yine $\mathrm{O}$, sünnet hitaplarının muradını anlamanın ve onu delillendirmenin, sünnetten yalanı ve anlaşılmazlığı nefyetmeyi ispatlamaya ihtiyacı olduğu görüşündedir.

Dolayısıyla ilk akıl vesilesiyle sünnete temessük gerçekleşmesi gerekir. ${ }^{27}$ Şu halde onun düşüncesine göre Kur'an ve sünnet, kendi delaletlerinin shhhati konusunda akla dayanmaktadır. Zira kitap ve sünnet perspektifinden her şeyi doğru bir şekilde anlamak şu esasa dayanmaktadır: Allah Teâlâ bir sıfata sahiptir ve o sıfatın varlığı ile kabih/çirkin işleri ihtiyar etmez. Bu asıl da sadece akıl ile bilinir ve idrak edilir. Akıl açısından Allah'a ilişkin böyle bir tanıma imkânı olmadığı zaman ancak diğer kaynakların (Kitap, sünnet)

Kadı Abdulcebbar, II, s. 1-3, 30-32

Kadı Abdulcebbar, II, aynı yer, s. 32.

Kadı Abdulcebbar, II, aynı yer, s. 33.

$\begin{array}{ccc}\text { Kelâm Araştırmaları Dergisi } & \text { C.: 13, } & \text { S.: } 2 \\ \text { Journal of Kalâm Researches } & \text { V.: 13, } & \text { I.: } 2 \\ \text { [KADER-e-ISSN: 1309-2030] } & 2015\end{array}$


haber verdiği bilgiler kesp edilebilir ve dinî bilgi adına onlara temessük edilir. ${ }^{28}$

Kadi Abdulcebbar, Allah kelaminın, tevhid ve adalet gibi hususların akliyatına delalet etmediğine inanır. Zira Kur'anî verilerin delaletine dair bilgi, ondan daha mukaddem olan bir şeye muhtaçtır. Şayet bu veriler kendi nefsinde/fî nefsih- böyle bir delalete sahip olsalar, kendi aslına delil olmuş olmaları gerekir. Hâlbuki fer', kendi aslına delil olamaz. Zira bu durumda tenakuz meydana gelir. Bu yüzden fer', anlamlarını bilmek için akla muhtaç olduğumuz bir şeye bir delaleti yoktur. ${ }^{29} \mathrm{O}$, başka bir yerde bu hususu şöyle açıklamaktadır: Kur'an hitaplarının bir kısmını sadece akıl yollu anlamak mümkündür. Bu beyanlar, tevhid ve adalete ilişkindir. Zira

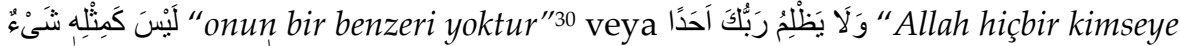

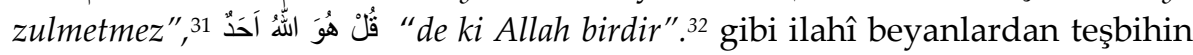
nefyi, Allah'in adaleti ve tevhid bilinemez. Zira insan, daha önceden bu konulara ilişkin bilgi ve marifeti olmadıkça Allah'ın hitabının hak olduğunu bilemez. Böyle olduğuna göre bunlara ilişkin ilk marifet olmadıkça ilahî hitabın sıhhati de malum olmaz. Şu halde bu ayetler ve beyanlar ile nasıl ihticac ve istidlalde bulunulabilir? ${ }^{33}$ Mu'tezile, aklî ve şeri' bilgi olmak üzere iki tür bilgi düzenine inanır. Mu'tezile bilginleri, şeri' bilginini aklî bilgiye tabi olduğuna inanırlar.

Mu'tezile düşünürlerinden Ebu'l-Hasan Basrî, (ö. 110/728) el-Mu'temed fi usûli'l-fikh, adlı kitapta bilgi elde etmenin yolları hakkında bir bap açmış ve orada şöyle demiştir: Üç̧ yoldan eşyaya ve işlere ilişkin bilgi elde edilir: Ya sadece akıl yolu ile onlara dair bilgi elde edilir, ya şeriat ve dinî beyan vasıtasıyla bilgi elde edilir ya da her iki yolla. ${ }^{34} \mathrm{O}$, devamla şöyle der: Akıl ile bilebileceğimiz işler, bir takım hususlardır ki, akıl yolu ile bunlara dair delil ortaya konabilir ve dinî beyanların doğruluğuna ilişkin bilgi, bunları bilmeye bağlıdır. Allah'ı ve ilahi sıfatlarını tanıma, Allah'ın Ğanî olduğunu ve kabih işleri yapmayacağını bilme gibi. Hasan Basrî'nin görüşüne göre bu zeminde akıl, asıl ve esastır ve şeri'n sıhhati de ona dayanmaktadır. Zira bizler şerî' verilerin sıhhatine dair bilgi sahibi olduğumuz zaman (mucizeleri yoluyla) peygamberlerin sıdkı hakkında bilgi elde etmiş oluruz. Mucizeleri vasıtasıyla peygamberlerin doğruluğuna vakıf olduğumuz zaman da Allah'ın, mucizeleri yalancının eliyle gerçekleştirmediğini biliriz. Bu konu hakkında bilgi sahibi olduğumuz zaman da mucizeleri yalancilar eliyle gerçekleştirmenin kabih bir iş olduğunu ve Allah'ın kabih bir işi yapmayacağını anlarız. Allah'ın kabih bir işi yapmayacağını bildiğimiz anda

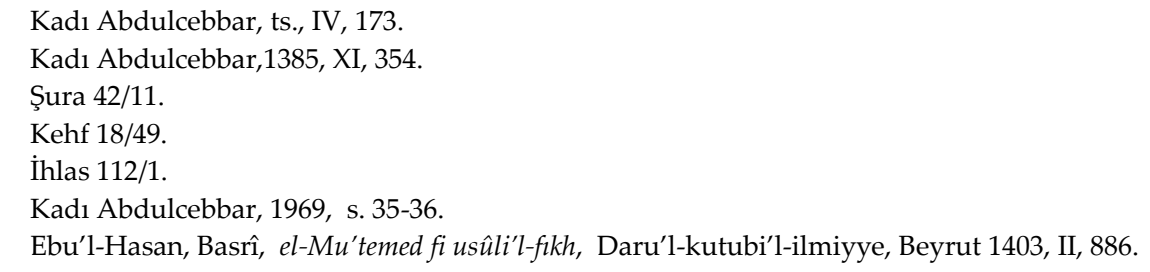

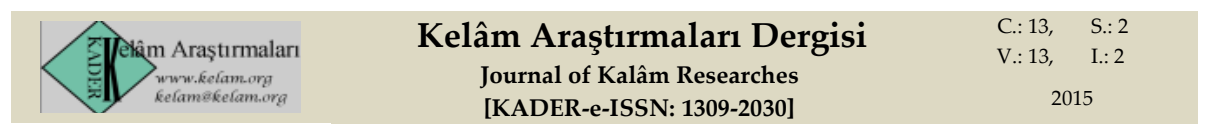


da O'un, kubhun kabih olduğunu ve kabih iş yapmaya ihtiyacı olmadığını bildiğini biliriz. (âlim) Bu ferî' işleri bilmek Allah'ı tanıma bilgisine dayanır. Bütün bu aklî veriler ve bilgiler, şerî' beyanlardan önce gelir ve şer' bunlara yol bulamaz. Bu varsayım üzerine şerî́ verilerin sıhhati, hepsi de aklî olan pek çok öncül verilerin ispatına bağlıdır. ${ }^{35}$

Kadi Abdulcebbar da dinî bilgilerin yekdiğeri üzerindeki tertibi konusunda bu noktayı şöyle anlatmaktadır: Tanımak ve bilmek/marifet, birinci derecede, tevhid ve adalete matuftur. Daha Sonra da ilahî emir ve nehiyleri tanımak gelir. Bu üçlü marifet (tevhid, adalet ve tekâlif), üç tür delil ve delalet ile elde edilir ve bunların tertibi şöyledir:

1. Sihhat ve vücuba delalet türünden olan delil. Bu delil ile tevhid bilgisi/marifet yolu bulunabilir.

2. Devâ̂ি'lere delalet eden delil. Bu delil, ilahi adaleti tanım aile neticelenir.

3. Anlaşma ve işbirliğine dayanan delil. Bunla yükümlülükler/tekâlif tanınmış olur. ${ }^{36} \mathrm{Bu}$ konuya dair önemli nokta şudur: Üçüncü delalet, mantık olarak önceki iki merhaleye terettüp eder ve onlara bağlıdır. Böylece vahiyden ilahî muradı ve maksudu iyice anlama, Allah'ı, O'nun zatî ve fiilî sıfatlarını aklî olarak tanımaya bağlı (olduğu anlaşılmakta)dır.

\section{3. İlk Vaz'a Dair Bilgi ve Mütekellimin/Allah'ın Kastı}

Şeri' beyanın sıhhatinin aklî delillere muhtaç olup ona dayandığı yolundaki noktanın iyice anlaşılması gerekir. Mu'tezile'nin bakış açısına göre dilin vazı', karar vericiliği ve mütekellimin maksadını anlama/tanıma hususundaki bilgiler oldukça önemlidir. Mu'tezilîlerin itikadına göre her bir söz, bu cümleden Tanrı sözü, iki şart ile anlam kazanır ve anlaşılmaya kabil olur: 1. İşin içinde ilk vaz'ın olması 2. Mütekellimin kastını bilmemiz ki, bunun gereği de zaten $\mathrm{O}^{\prime}$ nun sıfat ve fiillerini tanımaktır. Onlara göre böyle bir tanıma, aynı zamanda aklî bir tanımadır. Bu nedenle dilsel delaletler, aklî delaletlere tabidir ve ondan sonra gelir.

İlk vaz' hakkındaki bilgiye gelince Mu'tezile, nassçı olan hadis ehli ile Eş'arîlerden farklı düşünür. Dilde lafız-mana ilişkisi, beşerî vaz' ve muvazaaya tabidir ve Allah tarafından olmayıp ve tevkifî değildir. Binaenaleyh, bu vaz' hakkında bilgi olmaksızın karşılıklı anlama/anlaşma imkânı yoktur. Allah kelamı dâhil, başaklarının kelamını da anlama imkânı olmayacaktır. Zahirîler ile Eş'arîler, dili tevkifî bilirler. Mu'tezile itikadına göre mütekellimin kastını bilme konusuna gelince bir kimse Allah'ın sözünde, dinî ve şerî’ nasslarda mütekellimin kastını bilmedikçe onları

35 Ebu'l-Hasan Basrî, aynı yer.

36 Kad1 Abdulcebbar, 1385, XVI, 349.

\begin{tabular}{|c|c|c|}
\hline Alâm Araștırmaları & $\begin{array}{l}\text { Kelâm Araştırmaları Dergisi } \\
\text { Journal of Kalâm Researches } \\
\text { [KADER-e-ISSN: 1309-2030] }\end{array}$ & $\begin{array}{cc}\text { C.: } 13, & \text { S.: } 2 \\
\text { V.: } 13, & \text { I.: } 2 \\
2015\end{array}$ \\
\hline
\end{tabular}


anlamaya nail olamaz. Şu halde Allah'ın dinî deliller ile Kur'an ayetlerindeki maksudu, ancak tevhid ve adalet tanındıktan sonra anlaşılabilir. Fakat zahirîler, hiçbir zaman Allah'ın maksudunu anlamak için bir koşul olarak mütekellimin maksuduna ilişkin söz etmemektedirler.

Kadi Abdulcabbar bir kimse, daha önceden tevhid ve adalet hakkında aklen bir bilgi elde etmeden "Kur'an, tevhid ve adalete delalet eder" derse onun bu yöndeki iddiasının geçersiz olduğunun açı olduğunu vurgular. Zira kişi, mütekellimi (Allah'ı) ve sıfatlarını tanımaz, O'nun hak dışında bir söz söylemediğini bilmezse O'nun kelamının medlulü ile istidlalde bulunamaz ve ona dayanamaz. Zira onun kelamının sihhatine dair bilgi sadece daha önceden tevhid ve adaleti tanımasıyla mümkün olur. ${ }^{37}$ Başka bir ifade ile kişi, söz söyleyenin (Allah) sıfatlarından haberdar olması gerekir ve onun bu sıfatları tanıması da tamamen aklî delil yoluyla müyesser ve mümkün olur.

Hatta O, Kur'an ayetlerinin tefsiri için sadece Arap dilini, rivayet ilmini, fıkıh ve fıkıh usulü ilmini bilmeyi yeterli görmemektedir. Aksine $\mathrm{O}$, şöyle demektedir: Kim, Allah'ın tevhid ve adaletini, fıkhın delillerini ve şerî' ilimlerin hükümlerini bilirse Allah'ın kitabını tefsir etme girişiminde bulunabilir. Bu ilimleri bilmeyen kimsenin Allah'ın kitabını tefsire girişme hakkı bulunmamaktadır. O, devamla şöyle demektedir: Hiç kimse, Allah'ın tevhid ve adaletini, hangi sıfatların ona vacip, hangilerinin mümteni olduğunu, Allah'ın, hangi işi yapmasının hasen, hangisini yapmasının kabih olduğunu, muhkem ayetleri mütaşabih ayetlere hamledecek ve onları birbirinden ayıracak derecede bilmeden sadece (fıkıh, kitap, sünnet, icma, kıyas ve fıhkî deliller) gibi hususları bilmekle asla âlim olamaz. Bu ilimleri bilmeyen kimse, sadece Arapça'ya veya Nahive yahut sadece rivayete/hadislere dayanarak Allah'ın kitabını tefsire girişme hakkına sahip değildir. ${ }^{38}$

Bu esasa göre usul açısından Allah'ın zatî ve fiilî sıfatları yani tevhid ve adaleti bilinmeden şerî' hitapların delaleti ve beyanları bilinemez. Aksine bu hitapların delaleti, akıl ile bilinen hususlara dayanmaktadır. Sadece hitapların delaletine dair malumat mütekellimin kastını anlama yolunu açar.

\section{Tefsirde Mu'tezile'nin Akılcı Eğiliminin Teorik Dayanakları}

Şüphesiz, tefsir dalındaki muhtelif eğilimler, sahiplerinin özel fikirlerinin temelinde bulunmaktadır. Her bir müfessir, verili bu ilkelere dayanarak kendi özel metoduyla Kur'an'ı tefsir eder. Başka bir deyişle, özel düşünsel ilkeler ve her müfessirin bilgisi, Allah'ın ayetlerini nasıl tefsir ettiğini ortaya koymada belirleyici olmaktadır. İster müfessir, onlara iltifat etsin, ister emesin. Dediğimiz gibi, Kur'an tefsirinde Mu'tezile akılcılı̆̆ının temel

\footnotetext{
37 Kad1 Abdulcebbar, 1385, XVI, 395.
}

$38 \quad$ Kadi Abdulcebbar, 1408, 66, 607.

\begin{tabular}{|ccc} 
Kelâm Araştırmaları Dergisi & C.: $13, \quad$ S.: 2 \\
Journal of Kalâm Researches & V.: $13, \quad$ I.: 2 \\
[KADER-e-ISSN: 1309-2030] & 2015
\end{tabular}


ilkelerini araştırmak, onların tefsir ilkelerini ayrıntılı araştırmaya girme anlamına gelmemektedir. Belki maksat, tuttukları bu aklî eğilimin nedenini ve bunun, dayandığg bir dizi verili payeyi göstermektir.

Doğal olarak bu kısa araştırmayla Mu'tezile'nin kabul ettiği temel ilkeler ile tefsirde böyle bir yöneliş arasındaki mantıksal bağ açığa kavuşacaktır.

Bu nokta dikkate alınarak makalenin ikinci sorusuna yani tefsirde $\mathrm{Mu}^{\prime}$ tezile akılcılığının temel sebeplerine dönelim. Mu'tezile'nin bakış açısından hareketle akıl, başta Kur'an ayetleri olmak üzere dinî bilgileri tahlil etme ve anlamada birinci derece rol oynamaktadır. Kişi, aklın verilerinden istifade etmekle nazar ve istidlal merhalesini elde eder ve doğru yoldan kendisi için bilgileri iktisab eder. Acaba tefsirde Mu'tezile bilginlerinin akılcıllı̆g hangi temel esaslar üzerine bina edilmiştir? Genel olarak şöyle söylenebilir: Kur'an ayetleri tefsirinde $\mathrm{Mu}^{\prime}$ tezile rasyonalizminin eğilimi; varlığı bilme, insanı tanıma, Kur'an'1 anlama, dili bilme, Kur'an konusunda özel bir metoda sahip olma ve onların nasıl anlaşılması gerektiği gibi bir dizi temel usul ve öncüllere dayanmaktadır. Bunları tahlil edip anlamadan böyle bir akılcı yolun izlenmesinin anlaşılması mümkün olmayacaktır. Makalenin devamında bunların en önemlilerini açılamaya çalışacağız.

\subsection{Kur'an'ın Hâdis Olması}

Kur'an tefsirinde İtizalî akılcılığın önemli esaslarından birisi Kur'an'ın hadis olduğuna inanılmasıdır. Kur'an'ın mahlûk olduğuna dair itikat, Sünni kelam fırkaları arasında Mu'tezile'nin en önemli ayrıcalıklı özelliklerinden sayılmaktadır. Onların bakış açısına göre insan, Kur'an'ın muhatabı ve mesajlarının tarafıdır. Kur'an metni ilahî bir fiil olarak hadis ve mahlûktur. Kadim ve ezelî değildir. Şu halde Kur'an'ı Allah'ın fiili sıfatlarından bilmek ve onun zatî sıfatlarından ayırmak gerekir. ${ }^{39}$ Buna karşılık Eş'ârîler, hadis ehli ve diğer Zahirîler Kur'an'ın kadim, ezeli ve Allah'ın zatî sıfatlarından olduğunu iddia etmişlerdir. ${ }^{40}$

Kur'an'ı anlamaya yönelik bu iki akımın kendine özgü zaruretleri bulunmaktadır. Elbette Kur'an bilim ile ilgili bu temel görüş ayrılığı, Eş‘arîlerin dediği şekilde- ilahî kelamın kadim ve zatî oluşu, ya da Mu'tezile'nin dediği gibi- Kur'an'ın hâdis ve Allah'ın fiili sıfatlarından oluşu, temelde dil bilimsel bir ihtilafın bir sonucudur. Buna göre Eşarîler, ilahî kelamın gayrı mahlûk ve zâtî olduğuna inanıp ilahi diyalogun tevkıfî olduğu görüşündedirler. Bu temel esasa olan inanç mukaddes metnin zahiri manasını tekit etmeyi gerektirmektedir. Zira ilahi kelam kendi gerçek/zahir/müstakim anlamında kullanılmıştır. Onun zahiri ne demişse muradı da odur. Dolayısıyla aklî karinelerle başka bir manaya tevil edilmeye ve çevrilmeye kabil değildir. Bu zahircîliğin sonucu olarak bütün iyi ve kötü

Kadı Abdulcebbar, 1385, VII, 84-94.

40 Bkz. Bakıllânî, Muhammed b. Tayyib, el-İnsâf fî mâ Yecibu I'tikaduhu vela Yecuzu'l-Vehlu Bih, Tsh. Muhammed Zahid Kevserî, el-Mektebetu'l-Ezheriyye, Kahire 1413, s. 71.

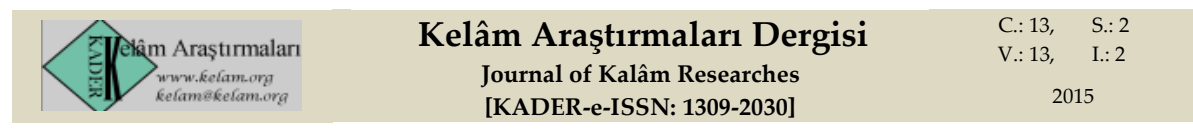


hadiseleri/fiilleri Allah'ın iradesine, takdir ve meşietine intisap etmek caizdir. Her ne kadar bu, aklen kabih ve çirkin olsa da böyledir. Fakat Mu'tezile'nin bakış açısına göre dil beşer ürünü bir şeydir. İlahî kelam dahi beşeri dil formatında ve kaideleri çerçevesinde ilka olmuştur. Şu halde Kur'an tefsiri ve Kur'an'ı anlamada beşer diline hâkim olan kaidelerden yararlanmak gerekir ki, aklî karine ve kaideler de bu türdendir. Öte yandan Kur'an beşer aklına hitap etmektedir. Öyleyse onu anlamak da aklî esaslara dayanmaktadır. Mutezililer Kur'an'ın kadim oluşunu akla aykırı görmüş ve bu iddiaları için aklî deliller de ortaya koymuşlardır. ${ }^{41}$

Her halükarda Kur'an'ın mahlûk olduğuna dair inanç, Mu'tezile'nin Kur'an ve Kur'an tefsirindeki teamülünde özel bir şekilde öne çıkmaktadır. Kur'an, kelimeler, harfler, sesler ve söyleyiş bakımından beşerîdir, edebî ve dilsel çalışmaların sonuçlarına tabidir. Dilbilimciler bu konuda ittifak halindedirler. Bunun için kaideler ve usuller tedvin etmişlerdir. Binaenaleyh, Allah'ın kitabının tevil ve tefsiri konusunda insan aklı için geniş bir alan açılmakta, tevil ve istiare ayağı da açılmış olmaktadır. Buna ek olarak Allah kelamının beşer ile eşzamanlı olması, o kelamın herkes tarafından anlaşılır olmasını gerektirmektedir. Bu nokta insan akılcılığının ilahi kelam ile kesişmesine yol açmaktadır. Mu'tezile de buna inanmaktadır. Öte yandan eğer Kur'an'ı ilahi fiil bilirsek bu, Kur'an'ın her türlü yalan ve batıla bulaşmamış olmasını, beyanlarının doğru ve hikmete uygunluk arz etmesini gerektirir. Bu aynı zamanda Mu'tezile'nin Kur'an ayetleri tefsirinde önemle vurguladığı başka bir noktadır.

\subsection{Kur'ân'ın Tefsir Edilebilirliği}

Kur'an tefsirinde Mu'tezile akılcılığının temel usullerinden bir diğeri de Kur'an tefsirinin, peygamber ve sahabe dişındakiler tarafından yapılmasının mümkün olduğuna dair inançtır. Kendi kelamî görüşlerini Kur'an'dan ilham yoluyla aldığını ileri süren Mu'tezile, Kur'an tefsirinin sadece $\mathrm{Hz}$. Peygamber'e ve sahabeye tahsis edilmesini kabul etmemiş, onun tefsirinde aklın ve içtihadın özel bir yeri olduğuna inanmışlardır.

Tıpkı tefsir tarihinde olduğu gibi sahabe döneminde Allah kitabının tefsiri daha çok bizzat ayetlere ve peygamberden yapılan rivayetlere dayanılarak yapılıyor, tefsirde rey ve içtihada ise fazla önem verilmiyordu. Ancak rey ile tefsir kapısını aralayan İbn Mes'ud'u bunun dişında tutmak mümkündür. Tabiîn asrında Mücahid ve İbn Mes'ud'un bazı talebeleri, tefsirde, Kur'an ayetlerine, peygamberin rivayetlerine, sahabe sözlerine ek olarak bir noktaya kadar da rey ve içtihattan istifade etmişledir. Isşte bu dönemde Kur'an ve Kur'an ayetlerinin tefsirinde takip edilen metot konusunda ihtilaflar artmıştır. Böylece her grup ve fırka, kendi özel düşünceleri ve inanç esasları çerçevesinde tefsire girişiyor, fakat çoğu zaman bu tefsirler diğer fırkalar tarafından kabul görmüyordu. İşte böyle bir atmosferde

$41 \quad$ Kadi Abdulcebbar, 1408, s. 531.

\begin{tabular}{|c|c|c|}
\hline elâm Araştırmaları & $\begin{array}{l}\text { Kelâm Araştırmaları Dergisi } \\
\text { Journal of Kalâm Researches } \\
\text { [KADER-e-ISSN: 1309-2030] }\end{array}$ & $\begin{array}{cc}\text { C.: } 13, & \text { S.: } 2 \\
\text { V.: } 13, & \text { I.: } 2 \\
2015\end{array}$ \\
\hline
\end{tabular}


Mu'tezile'nin akılcı düşüncesi ortaya çıkmıştır. Bazı Kur'an uzmanları, İtizâlî düşüncenin bu ortamda ortaya çıkışını -ki Mu'tezile, Allah'ın sıfatlarını kabul eden donuk zahirî düşüncenin boyunduruğu baskısı altındaydı- sıfatları kabul eden tabakaya aleyhinde bir tür fikrî başkaldırı olarak değerlendirmiştir. ${ }^{42}$

Zahire yönelen fırkalara karşın, Mu'tezile, Kur'an dilini bilen ve onun tefsir şartlarını taşıyan herkes için Kur'an hitaplarını anlamanın mümkün ve müyesser olduğuna inanır. Kadi Abdulcebbar'ın inancına göre Allah'ın kelamı, onun muradına delalet eder. Onun muradını derk etmek de ayrıcalıklı değildir. Belki gerekli şartlara sahip olan diğer ilim ehli de Kur'an'in tefsirini bilebilir. Kur'an'in tevil ve tefsirini sadece peygamber ve imam(lar)a tahsis eden görüş doğru değildir. ${ }^{43} \mathrm{Bu}$ nedenle Kadi Abdulcebbar, Kur'an'ı anlama ve yorumlamayı peygambere ve sahabeye tahsis eden veya onun yorumunun, bir takım batınî manaları ve remizleri kapsadığını ve bunu anlamayı da sadece bazı şahısların iradesinde gören görüşleri ret etmektedir.

Kadi Abdulcebbar, Kur'an tefsiri ve yorumu konusunda doğru olmayan nazariyeleri değerlendirerek Kur'an'ı anlama ve yorumlamada bu nazariyelerin sorunu olarak zahirîliği, hadsiçiliği ve batınîliği görmektedir. Aslında ona göre bunların hepsi, "akla değer vermeme" ve "Kur'an'1 anlamada aklı çalıştırmama" konusunda müşterektirler. Onun inancına göre Kur'an'1, "anlamı olmayan bir kitap olarak gören, onun nüzulünün sadece iman ve tilavet için olduğunu iddia eden nazariyeden tutun ta Kur'an'ı anlamsız görüp de bu anlamı bilmenin imkânız olduğunu, bunu anlamayı peygamberle sınırlayıp onun rivayetlerine müracaat etmeyi gerekli görenlere, Kur'an'ın bütün muhtevasını onun zahirinde görüp de onun tefsirini peygamber, sahabe ve tabiîn dışındakiler için imkânsız ve caiz görmeyenlere, onun manasını zahirî değil de batınî görüp onun bilgisini peygambere ve imama has bilenlere veya batınî manasına kail olmayıp onun tefsirini imama tahsis edenlere varıncaya kadar pek çok nazariyeler vardır. ${ }^{44}$ Dolayısıyla herkes bu zaaf noktasında ortaktır. Bu nedenle Kadi Abdulcebbar, bu görüş sahiplerinin Kur'an'a ve İslam'a indirdikleri darbelerin, muhaliflerin ve mülhitlerin Kur'an'a vurdukları bütün darbelerden çok daha büyük oluğunu iddia emiştir. ${ }^{45}$

Mu'tezile düşüncesine göre tefsir için gerekli olan şartlardan yararlanıldığg halde herkes için zahirinden Kur'an'ı anlamanın imkânsızlığı ve Kur'an'ın muradını anlamayı özel bir gruba hasretme ilahî fiillerin garazı ile uyuşmamaktadır. Şu anlamda ki, Kur'anî hitapların amacı, yol gösterici

42 Muhammed Hadi, Marifet, et-Temhîd fì Ulûmi'l-Kur'ân, en-Neşru'l-İslamî, Kum, h.1415, III, s. 76.

43 Kadi Abdulcebbar, 1385, XVI, 369.

44 Kadi Abdulcebbar, aynı yer, 345.

45 Kadi Abdulcebbar, aynı yer, 345.

\begin{tabular}{|ccc} 
Kelâm Araştırmaları Dergisi & C.: $13, \quad$ S.: 2 \\
Journal of Kalâm Researches & V.: $13, \quad$ I.: 2 \\
[KADER-e-ISSN: 1309-2030] & 2015
\end{tabular}


mesajları bütün insanlara ulaştırmaktır. Buna binaen bu hitapların herkes için anlaşılmaya uygun olması gerekir. Bu garazı ondan çekip alırsak Allah'ın fiili abes ve beyhude olmuş olacaktır. Hâlbuki Müslümanlar, her zaman Kur'an'a müracaat etmiş ve Kur'an'ın zahirleri, umum için şerî́ hükümlerin kaynağı olmuştur. Eğer onlar için Kur'an'ın zahirini anlamak mümkün olmazsa Kur'an'a müracaat anlamsız ve abes olmuş olacaktır. ${ }^{46}$ Kur'an mesajını anlamayı (sözgelimi ashap) gibi has bir gruba hasretmeyi nefyeden diğer bir nokta da şudur: Kur'an'ı anlamanın yolu, Arap diline aşina olmaktır. Çünkü Kur'an Arapçadır. Öyleyse bu dil ile ilgili yeterli bilgisi bulunan herkes, ayetlerin zahirinden Kur'an'ın muradını/mesajını anlayabilir. Diğer insanlar, Ashap ve selef ile dil yeterliliği ve özellikleri konusunda ortak iseler onların Kur'an'ı anlama imkânları olmadığını söylemek doğru değildir. ${ }^{47}$

Öte yandan eğer insan hidayet yolunu bulmak için ilahi kitabın ve onun öğretilerinin muhatabı ise bu durumumda Kur'an da Allah ile beşerî akıl arasında bir vasıta ve köprü konumunda olacaktır. Bu karşılıklı irtibat da sadece Kur'an'ın muhataplar tarafından anlaşılması ve beşerî akıl ile onun tefsir edilmesi olanaklı varsaymakla gerçekleşecek ve genel ilahî hidayet de kitabı aracılığıyla tahakkuk edecektir. Binaenaleyh, Kur'an'ın tefsir edilebilirliğinin gereği, onun ayetlerini akıl meydanında anlama ve ona aklî bir bakışın lüzumunda ortaya çıkmaktadır.

\subsection{Akıl-Kur'an Uygunluğu}

Kur'an tefsirinde Mu'tezile akılcllı̆̆ının diğer ilkesi, aklî hükümlerin/yargıların Kur'anî verilerle uyumlu olmasına olan inançtır. Mu'tezile'nin görüşüne göre Tanrı kelamının, aklî verilerle elde edilen delalete muhalif olması mümkün değildir. Mu'tezile âlimleri, ilahiyat ve usulüddin konusunda akıl ile nakil arasında bir çelişki olduğunu kabul etmezler. Tam aksine bu konularda aklı nakle öncelerler. Gerçekte burada aklî deliller ile naklî deliller arasında bir tearuz görmezler. Çünkü onlar, aklın hücciyetinin asıl, naklin ise fer' olduğuna inanırlar. ${ }^{48}$ Fer' de asla aykırı olamaz. Nakli akla öncelemek, fer' vasitasıyla aslı iptal etmek anlamina gelir. Gerçekte bu bir bakıma fer'i iptal etmektir. Eğer bir şeyin ispatı kendi nefyini beraberinde getirirse bu, tenakuz ve batıldır.

Mu'tezile bilginlerinin dediği gibi akıl ile nakil arasında çelişki olamaz. 'Şeriat, aklın lazım görmediği bir şeyi vacip kılar,' yargısı doğru değildir. Zira ikisi arasındaki ilişki, icmal ve tafsildir. Yani şeriatta varit olan bir takım hususlar, aklın yanında icmali olarak mukarrer/yerleşik ve sabittir. ${ }^{49}$ Öyleyse akıl ile nakil arasında bir tearuz ortaya çıkarsa akli, naklin önüne geçirmek

\footnotetext{
Kadi Abdulcebbar, 1385, aynı yer, 362.

Kadi Abdulcebbar, 1385, aynı yer, 362.

Kadi Abdulcebbar, 1408, s. 88; 1385, XVI, s. 354.

49 Kadi Abdulcebbar, 1385, XV, 117.
}

\begin{tabular}{|c|c|c|}
\hline detâm Araștırmaları & $\begin{array}{l}\text { Kelâm Araştırmalari Dergisi } \\
\text { Journal of Kalâm Researches } \\
\text { [KADER-e-ISSN: 1309-2030] }\end{array}$ & $\begin{array}{cc}\text { C.: } 13, \quad \text { S.: } 2 \\
\text { V.: } 13, \quad \text { I.: } 2 \\
2015\end{array}$ \\
\hline
\end{tabular}


gerekir. Bunun sebebi onların, aklı, -bizzat ve hakiki olarak- daha faziletli ve daha tercihe şayan gördüklerinden değildir. Tam aksine bunun sebebi, aklın rütbesinin daha önce gelmiş olmasından ötürüdür. Onlar, akıl Allah'a iman ve onun emirlerine teslim olmaya hükmettiği zaman bunun kolaylaştığına inanırlar. Başka bir ifade ile şer', akıl vesilesiyle tanınır. Ortaya çıkan tearuz da ya aklî delillerin önermelerinde bir hata vesilesiyle ya da naklî delilin hatalı anlaşılmasıyla ortaya çıkmaktadır. ${ }^{50}$

Onlar, genel olarak, akıl dışında gidilecek başka bir yol olmayan hususlarda sözgelimi, naklin nazarının, "Allah hakimdir, adildir, kabih işi yapmaz ve onu emretmez" gibi aklî bir hükümden teferru ettiği yerlerde ilk önce aklın nazarını naklin önüne geçirirler. Onların itikadına göre akıl vasıtasıyla bu konu açıklığa kavuşmadan önce hiçbir nakle temessük edilemez. Bu ve aklın kesin hüküm verdiği yerlerde eğer naklin zevahiri aklın açık hükmüyle çelişirse aklın hükmü mümkün mertebe nakle takdim edilir ve aklın açık hükmüyle uygun hale gelmesi için naklin zahiri de tevil edilir.

Kadi Abdulcebbar, şöyle der: Mükellef için gelen şerayi ve mesalih/yasalar ve yararlar, her şeyden önce onun /mükellefin aklına mutabıktır ve yükümlülerin ihtilaflarının tabi olduğu adab, gelenek rüsum ve tecrübe gibi pek çok meselelerle de mütenasiptir. İddia edilen bu hususun delili de şudur: Nakil ve sem' yoluyla gelmiş bilgiler, ilmî ve kesindir. Zira bunların hilafı imkânsızdır. Aynı şekilde aklî verilerin hilafı da caiz değildir. Yine bu sebeple nakil ve sem' yoluyla elde edilenler, tekliftir. Aynı şekilde akıl ile bilinen şeyler, Allah tarafından tekliftir. İnsan aklının, her iki kısmı tanıma, onların vücübunu ve nasıl vacip olduklarını bilme konusunda bir ihtilafı bulunmamaktadır. Bu nedenle, teklifin/yükümlülük aslı, aklın gereğidir. Sem' (nakil) de aklı gerektirmekte ve aklın hükmü bu iki gereklilik konusunda da birinden farklı değildir. ${ }^{51}$

Kur'an ayetlerini anlama ve tefsir etme konusunda sadece inancin ve akılvahiy arasında bütünlüğü ve iltizamı sağlamanın gereği de olsa aklî eğilim işletilebilir. $\mathrm{Bu}$ nedenle $\mathrm{Mu}$ 'tezile âlimleri, kendi metotlarına uygun bir şeklide zahirlerini akla muhalif gördükleri ayetleri aklî esaslarla uyumsuzluğunu giderecek şekilde tevil etmişlerdir.

Elbette bazı Mu'tezilîler de aklın bir başına çözümüne yol bulamadığı itikada ilişkin konularda sahih ve muteber olan nakil yoluyla çözümün elde edilmesi gerektiğine inanmaktadır. Fakat bütün bunlar yine de akıl ile uyumludur. Mesela Kadi Abdulcebbar, büyük günah işleyenlere öngörülen cezanın miktarını aklın yalnız başına çözümüne yol bulamadı̆̆ı

50 Mehrî Hasan, Ebu Sa'de, el-İtticahu'l-aklî fi müşkileti'l-marifeti inde'l-Mu'tezile, Daru'-fikri'lArabî, Kahire 1413, s. 42.

51 Kadi Abdulcebbar, 1385, XV, 114.

\begin{tabular}{|c|c|c|}
\hline Alâm Araștırmaları & $\begin{array}{l}\text { Kelâm Araştırmaları Dergisi } \\
\text { Journal of Kalâm Researches } \\
\text { [KADER-e-ISSN: 1309-2030] }\end{array}$ & $\begin{array}{cc}\text { C.: } 13, & \text { S.: } 2 \\
\text { V.: } 13, & \text { I.: } 2 \\
2015\end{array}$ \\
\hline
\end{tabular}


meselelerden olduğunu açıçca ifade etmekte ve bunu derk etmenin yolunun nakil olduğunu aktarmaktadır. ${ }^{52}$

\section{Tevhid ve Adalet Konusunda Dinî Beyanların Yol Göstericiliği}

Kur'an tefsiri ile ilgili Mu'tezile akılcılığının bir diğer esası da tevhid ve adalet alanıyla ilgili naklî beyanların belirleyici ölçüde yol göstericiliği sayılabilir. Mu'tezile'nin dinî bilgi ve Kur'an tefsiri konusunda tertip açısından aklı mukaddem saydığı ve nakil konusunda akıl yoluyla varit olan bütün konuların, aklı teyit ve tekit için olduğu noktasını dikkate almak gerekir.

Kadi Abdulcebbar, hocası Ebu Ali Cubbaî'den nakilde bulunarak şöyle der: Kur'an'in tevhid ve adalet konusunda ortaya koyduğu şeyler, bu alanda aklın derkini ortaya koymak içindir. Şayet aklî idrak dikkate alınmadan bu tür Kur'anî meseleler, tevhid ve adalete dair kendileriyle istidlalde bunabilmek için bir başına müstakil delil olmak isteseler, bu muhal olur. ${ }^{53}$ $\mathrm{Bu}$ esasa göre bu tür beyanlar bir başına -zaten- delil sayılmazlar ve başlangıç suretinde kendileriyle istidlalde bulunmak da mümkün değildir. Kadi Abdulcebbar, hocasının görüşünü naklettikten sonra onun görüşünü vurgular.

Zemahşerî de peygamberlerin gönderiliş amacının gafleti ortadan kaldırmak ve aklî verilere dikkati çekmek olduğunu belirterek şöyle yazmaktadır: İnsanlar, "neden Allah bize, bizi gafletten uyandıran ve aklî delillerle dikkatimizi çekip uyaran bir elçi göndermedi", demesinler diye onları bilgilendirmek, akletmeye yönlendirmek ve gaflet uykusundan uyandırmak amacıyla peygamberler gönderilmiştir. ${ }^{54}$

Binaenaleyh, Kur'an veya hadis nasslarının aklın hükmüne muvafık olduğu yerlerde Mu'tezile, bu nassların aklın hükmünün teyit amaçlı olduğuna inanır. Birinci eksende dediğimiz gibi, Mu'tezile, ilk rolü akla biçmekte ve akla öncelik tanımaktadır. Mu'tezile âlimleri, başka bir şey için değil, aklın teyidinden istifade etmek amaciyla nakilden istifade ederler. Zira onlar, nakle müracaat etmeden önce aklın verdiği hüküm yoluyla meseleyi açıklı̆̆a kavuşturmuş olurlar. Şayet nakilden bir teyit lazımsa onu ek delil olarak kabul ederler. ${ }^{55}$

\section{Sonuç}

1. Kur'an tefsirinde Mu'tezile akılcılığından maksat, şudur: Öncelikle onlara göre akıl, Kur'an'ı anlama ve yorumlamada

Kadi Abdulcebbar, 1408, s. 138,233.

Kadi Abdulcebbar, 1385, IV, 174-175.

Zemahşerî, 1407, II, 653.

Kadi Abdulcebbar, 1408, s. 768-769.

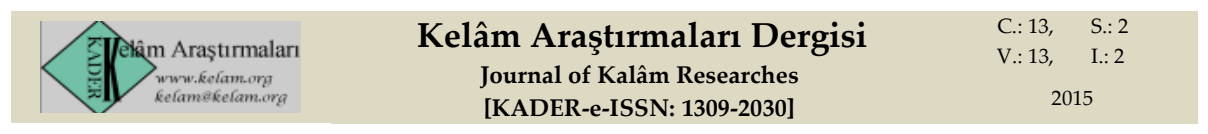


kullanılan deliller ve kaynaklar arasında ilk sırada, birinci derecede yer alır ve diğer delillerden önce gelir. İkinci olarak, şerî́ beyanların delalet yönü, sıhhat ve hücciyeti/delil oluşu aklî delillere dayanır ve onlara muhtaçtır.

2. Mu'tezile düşüncesine göre aklî delil, tevhidin ve adaletin hakikatini, Allah'ın zatî ve fiilî sıfatlarını idrak etme konusunda, müstakil keşfedici bir kaynaktır. Hatta akıl, ahlakın usul ve kaynağıdır. Bu nedenle dinî metinler, kendi kendilerine değil, bu aklî usul çerçevesinde şâri'n maksudunun anlamının ifade edicileri sayılırlar. Bu esasa göre "zahircilik", dinî metinleri ve bu cümleden Kur'an'1 anlamada merduttur.

3. İtizâlî akılcılık, bazı temel usul ve esaslara dayanmaktadır: Bunların en önemli olanları şunlardır: Kur'an'ın hadis olması, Kur'an'ın tefsir edilebilirliği, Kur'an'ın hitaplarında ve naklî hitaplarda akla dayalı izahlara vurguda bulunulması, aklın hükmü ile Kur'an'ın uyumu ve ikisinin çelişmezliği.

4. Mu'tezile bakış açısına göre insan, Kur'an'ın muhatabı ve onun mesajlarının tarafıdır ve Kur'an metni, ilahi bir fiil olarak kadim ve ezelî değil, hadis ve mahlûktur. Şu halde Kur'an'ın, Allah'ın fiilî sıfatlarına sahip olması gerekir. Bu yüzden Kur'an'ı anlama ve yorumlamada beşer diline hâkim olan kaidelerden yararlanılması gerekir ki, aklî karineler ve kaideler de bu cümledendir. Öte yandan Kur'an insan aklına hitap etmektedir. Öyleyse onu anlamak da aklî usule dayanmaktadır. Buna binaen Allah'ın kitabını tevil ve tefsir etme konusunda insan aklı için geniş bir alan açılmakta, tevil ve istiare yolu aralanmaktadır.

5. Mu'tezile'ye göre mahlûk ilahi bir kelam olan Kur'an'ı anlamak bir fert veya grubun tekelinde değildir. Zira bu durum, ilahi fiillerin hikmetiyle uyumlu değildir. Öte yandan eğer insan, hidayet yolunu bulmak için ilahi kitabın ve onun öğretilerinin muhatabı ise Kur'an metni de Allah ile beşer aklı arasında bir vasıta, irtibat ve köprü konumunda olacaktır: Karşılıklı bu irtibat da sadece beşer aklı açısından Kur'an'ın, müfessirleri ve muhatapları tarafından anlaşılması mümkün var saylamakla ancak gerçekleşecektir.

6. Mu'tezile'ye göre aklın hükmü ile Kur'an birbiriyle uyumludur ve akıl ile vahiy arasında bir ahenk bulunmaktadır. Buna göre Aklî deliller ile naklî deliller arasında bir tenakuz bulunmamaktadır. Belki aklî delil, asıl, naklî delil ise onun fer'idir. Dolayısıyla onlar, aklın hücciyyetini/delil oluşunun asıl, naklin hücciyetinin ise fer' olduğuna inanırlar. Fer' olan da asla muhalif olamaz. Nakli akla öncelemek, fer' vesilesiyle aslın iptal

\begin{tabular}{|c|c|c|}
\hline 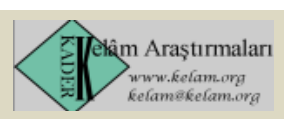 & $\begin{array}{l}\text { Kelâm Araştırmaları Dergisi } \\
\text { Journal of Kalâm Researches } \\
\text { [KADER-e-ISSN: 1309-2030] }\end{array}$ & $\begin{array}{cc}\text { C.: } 13, & \text { S.: } 2 \\
\text { V.: } 13, & \text { I.: } 2 \\
2015\end{array}$ \\
\hline
\end{tabular}


edilmiş olması anlamına gelir. Neticede bu da fer'in iptaliyle sonuçlanır.

7. Mu'tezile, tevhid ve ilahi adalet konularında nakli beyanların, aklın hükmünü iyice anlamayı vurgulamaya dönük olduğuna inanır. Bu nedenle onlara göre dinî bilgiler hususunda akıl sıralama açısından naklin önünde gelir. Buna binaen Kur'an veya hadis nassları, aklın hükmüne muvafık olmaları durumunda Mu'tezile bu nassları, aklın hükmünü teyit ettiğini var sayar.

\section{Son Ekler}

1. Örnekler için bakınız: Ahmed Hüseyin Şerifî ve Hasan Yusufîyan, 'Akl ve Vahy, Pejohişgâh-i Ferheng ve Endişe-i İslâmî, Tahran, 1383. Bu kitapta dinî anlama alanında Mu'tezile akılcılığı, usulüne uygun bir şeklide araştırılmış, fakat Mu'tezile bakış açısı ile aklın Kur'an tefsirindeki rolü ve yeri, yazarların ilgi alanına girmemiştir. Ayn yazarlar, Hiredgerâyi-i dinî, nigâhh-i nû be didgâh-i Mutezilé, Ma'rifet, Sayı: 51. Bu makale bir önceki eserin bir bölümüdür. Abbas Bahşî, Mutezilé, ve ruykerd-i 'aklân̂े be din, ittlaatı Hikmet Ve Marifet, sayı: 28. Bu makalede Mu'tezile'nin ortaya çıkış nedenleri araştırılmış, daha sonra kısaca dine akılcı yaklaşımları Mu'tezile bakış açısına göre akıl ve din mefhumu ve ikisinin birbiriyle ilişkisi araştırılmıştır.

2. Nasr Hamid Ebu Zeyd, el-ìtticahu'l-aklî fi't-tefsir, dirâse fî kadiyyeti'l-mecâz fi'l-Kur'an inde'l-Mu'tezile. Bu kitapta, tefsir konusuna dair Mu'tezile akılcılığı mücmel olarak ele alınmış ve onun bazı özellikleri üzerinde durulmuştur. Fakat yazarın asıl üzerinde durduğu husus, Mu'tezile'nin tefsirdeki mecaz anlayışıdır. 2. Ahmed Es'adî ve diğerleri, Âsibşınasî-yi ceryanhayi tefsirî. İkinci cilt, yedinci bölümde "Mu'tezile tefsir hareketi" başlığı altında bu hareketin akılcılığa yöneliş nedenleri üzerinde durulmuştur. 3. Abbas Humamî ve Hasan Recebzâde, "Mebânî ve reviş-i tefsir-i Mutezilé", Pejuhiş-i dinî, 19 sayı, 1388. Bu makalede, genel olarak Mu'tezile'nin akılcılığına dikkat çekilmiştir. 4. Muhammed Ali Esed Neseb, "Mebânî-yi tefsiri-yi Şia ve Mu'tezile", Kabasat, sayı: 57, Bu makale de genel olarak Mu'tezile'nin akılcılığına zımnen değinmiştir. 5. Hüseyin Muhammedî, Didgâha-yi Kur'an̂̀-yi Mu'tezile, Pejohişha-yi Kur'anî, sayı: 3, 1384. Bu makale de Mu'tezile'nin Kur'an tefsirinde aklın yeri konusuna yarım bir bakış yapmıştır. 6 . Hamid Melik Mekan ve Seyyid Hasan Talaqanî, "Çistî-yi 'akl der 'aklgerâyi-i Mu'tezilé" Kelâm-i İslâmî, sayı: 84. Bu makale,

\begin{tabular}{|c|c|c|}
\hline 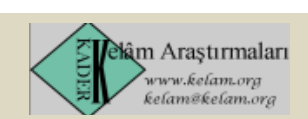 & $\begin{array}{l}\text { Kelâm Araştırmaları Dergisi } \\
\text { Journal of Kalâm Researches } \\
\text { [KADER-e-ISSN: 1309-2030] }\end{array}$ & $\begin{array}{cc}\text { C.: } 13, \quad \text { S.: } 2 \\
\text { V.: } 13, \quad \text { I.: } 2 \\
2015\end{array}$ \\
\hline
\end{tabular}


Mu'tezile bakış açısıyla aklın anlamı üzerinde durmaktadır. Bizim çalışmamız için bir öncelik yönü bulunmaktadır.

3. Bu bizzat Zemahşerî'nin tabiridir: şöyle der: “Din yolunda sultanın bayrağı altında hareket et. Bunun ve onun rivayetleriyle kanaat etme!" Zemahşerî, Mahmud b. Ömer Etvaku'z-zeheb, fi'lmevâiz ve'l-huteb, tahkik: Ahmed Abduttevvab İvaz, Daru'lfadile, Kahire, Makale: 37, s. 110. 


\section{Kaynakça}

Bakıllânî, Muhammed b. et-Tayyib, el-İnsâf fì mâ yecibu i'tikaduhu vela yecuzu'l-vehlu bih, Tsh. Muhammed Zahid Kevserî, el-Mektebetu'lEzheriyye, Kahire 1413.

Ebu'l-Hasan Abdurrahim b. Muhammed, el-Intisar, tahkik: Muhammed elHicazî, Mektebetu'-sekâfe, Kahire 1988.

Ebu'l-Hasan, el-Basrî, el-Mu'temed fi usûli'l-fikh, Daru'l-kutubi'l-ilmiyye, Beyrut 1403.

Eş'ârî, Ebu'l-Hasan, Mekâlâtu'l-İslâmîyyin ve ihtilafu'l-musallin, (3.Baskı), Daru'n-neşr, Beyrut.

Husnî Zeyne, el-'Aklu inden'l-Mu'tezile, tasavvuru'l-'akl inde Kadi Abdilcebbar, Daru'l-âfâk, Beyrut 1978.

Kadı Abdulcebbar, Ebu'l-Huseyn el-Hemedânî el- Muğni fì ebvabi't-tevhid ve'l-'adl, tahkik: Muhammed Mustafa Hilmî ve diğerleri, Daru'lMisriyye, Misir, 1385.

, Muteșâbihu'l-Kur'an, dirase mevduinye li'l-Kadi Abdilcebbar, b. Ahmed el-Hemedânî, tahkik: Muhammed Adnan Zerzur, Daru't-turas, Kahire 1969.

,Fadlu'l-i'tizâl ve tabakatu'l-Mu'tezile, Tahkik: Fuad es-Seyyid, Daru't-Tunusiyye, Tunus 1393.

, Şerhu Usûli'l-hamse, Tahkik: Abdukerim Osman, mektebetu Vehbe, Kahire 1408.

Lahorî, Muhammed İkbal, Seyr-i Felsefé der İrân, Femir Huseyn Âryanpûr , İntişarat-i Emir Kebir, Tahran 1357.

Mihrî Hasan, Ebu Sa'de, el-İtticahu'l-aklî fi müşkileti'l-marifeti inde'l-Mu'tezile, Daru'1-fikr el-'Arabî, Kahire 1413.

Muhammed Hadi, Marifet, et-Temhîd fì ulûmi'l-Kur'ân, en-Neşru'l-İslamî, Kum, h.1415.

Şenuka, Said, et-Te'vil bi't-tefsir beyne'l-Mu'tezile ve's-sünne, el-Mektebetu'lezheriyye-Daru'l-vefa, Misır ts.

Zemahşerî, Mahmud b. Ömer, el-Keşşaf an hakaiki ğavamidi't-tenzîl, (3.Bask1), Daru'l-kutubi'l-'Arabî, Beyrut, 1407.

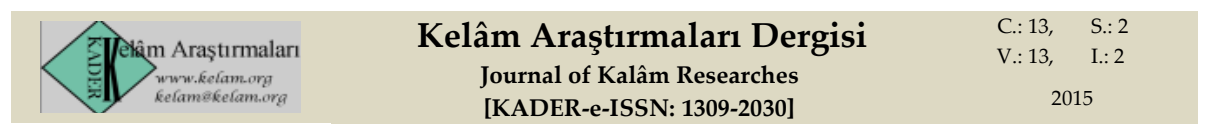

